\title{
How Do People Manage of Their Unused Medicines at Home?
}

\author{
Ni Made Ayu Nila Septianingrum ${ }^{1}$, Fitriana Yuliastuti ${ }^{2}$, Widarika Santi Hapsari ${ }^{3}$ \\ \{fitrianayuliastuti@ummgl.ac.id ${ }^{1}$ \} \\ Department of Pharmacy, Faculty of Health Sciences, Universitas Muhammadiyah Magelang 1,2,3
}

\begin{abstract}
This study aims to determine how the people in Magelang manage drugs especially stored and disposed drugs. This research is an observational study using simple random sampling method. Questionnaires containing drug disposal sites, types of drugs stored, beliefs about where to dispose of drugs and who should be responsible for drug waste were distributed using google form and directly visited people in the Magelang. Respondents who took part in this study amounted to 202 people. The results obtained in this study were that most people kept tablets / capsules (63.87\%) as drug supplies (66.80\%) with indications for colds and coughs $(28.81 \%)$. The public believes $(54 \%)$ that unused drugs can be disposed of in the trash $(61.80 \%)$. The conclusion of this study is that many people $(65 \%)$ have never received socialization about how to properly dispose of drugs so that many people dispose of drugs such as disposing of household waste in general, and people agree (43.1\%) if the medicine / container those that are not used are returned to the health facility. By disposing of drug waste in health facilities will prevent counterfeit drugs, illegal drugs and environmental damage.
\end{abstract}

Keywords: Dispose of Drugs, drug storage, and belief in throwing medicine

\section{Introduction}

Indonesia is a developing country with a population of 267 million people [1]. The results of the 2013 Basic Health Research stated that as many as 35.2\% of households in Indonesia performed self-medication as first aid in caring for themselves and their immediate environment [2]. The purpose of self-medication will be achieved by supporting factors, including how to store the drugs that have been purchased and how to dispose of drugs that are no longer used and how people get them. The results of the study stated that $65.01 \%$ of Indonesians performed self-medication if they were sick, this could be an indication that every house has a drug store so that each individual must know how to manage drugs properly and correctly [3]. One example of the negative impact that can occur if a drug is disposed of carelessly is environmental pollution by drugs [4]. Disposing of medical or medicinal waste is not the same as disposing of household waste. The form of the drug to be disposed of must be different from the original form research conducted in Sleman Yogyakarta found that $56.97 \%$ of drug waste was disposed of in the form of tablets or solids and 37.88\% in the form of liquid medicine packaging [5]. In Serang Public Health Center, $87.5 \%$ had poor medical waste disposal, due to the absence of definite guidelines for drug processing and limited funds to exterminate third parties [6]. Apart from polluting the environment, the negative impact that can occur is the opportunity for drug abuse to occur. This can happen because they do not get the medicine through official health facilities such as pharmacies, hospitals or clinics. The drugs that are widely abused are narcotics, 
psychotropic substances and other addictive substances (NAPZA) because certain individuals feel the side effects of the side effects. Improper disposal of drugs can result in drug reconditioning, because certain individuals experience these side effects. Improper disposal of drugs can lead to drug reconditioning, meaning that drugs that are no longer used/damaged/expired by improving their condition can be useful again. Drug waste that is not properly disposed of will be reprocessed (reconditioned) by irresponsible people so that the goal of treatment will not be achieved, it will cause undesirable things if consumed. Based on the description above, the researcher wants to know how people store and dispose of unused/damaged/expired drugs in order to minimize the negative impacts that will occur related to drug disposal and can support government programs, especially in the health sector (GERMAS).

\section{Method}

This research is a qualitative descriptive study conducted observational using a simple random sampling method. The questionnaire used is the adoption questionnaire [7], which contains variables of the respondent's personal data, drug dumps, forms and indications of stored drugs, beliefs about drug disposal sites and who should be responsible for drug waste. Primary data obtained by distributing questionnaires via google form and visiting people in the City and District of Magelang directly. Respondent data obtained as many as 202 people.

\section{Results and Discussion}

Most respondents in this study were women aged 23-27 years who were married and worked as housewives. According to data [8] in Magelang, Central Java, the group most economically inactive are those who work as housewives. This research is right on target with the dominant target being housewives. Housewives work 24 hours a day at home to take care of the house and their families, one of which is being the first person to manage medicines if someone is sick at home. Table 1 shows the data on the characteristics of the respondents.

Table 1. The characteristics of the respondents.

\begin{tabular}{ll}
\hline Variable & Percentage \\
\hline Female & $74 \%$ \\
Married & $57.43 \%$ \\
Age 23-27 Year old & $32.67 \%$ \\
Housewives Job & $41.09 \%$ \\
Income per Month < Rp. 2.000.000,- & $58.42 \%$ \\
The average cost of buying drugs $<$ Rp 100.000 & $84.16 \%$ \\
\hline
\end{tabular}

The results showed that people in Magelang kept more than one type of medicine at home and most of them were in the form of tablets/capsules (63.87\%). The tablet/capsule form is more widely used by the public. This is because it is practical for consumption, available in various dosage strengths, can be stored for a long time and is easy to swallow [9]. The second-largest dose of medicine stored in the household was syrup/liquid (20.17\%). Both of them are oral medications that are widely consumed by the public, both adults and children because liquid 
preparations are more likely for children because they are easy for children to consume and taste sweet. In Table 2, there are various forms of medicinal dosage stored at home:

Table 2. The stored dosage form of the medicine

\begin{tabular}{llll}
\hline No & Dosage Form & Total & $\%$ \\
\hline 1 & Tablet / Capsule & 152 & 63,87 \\
2 & Liquid/Syrup & 48 & 20,17 \\
3 & Cream/Zalf & 33 & 13,87 \\
4 & Powder & 2 & 8,4 \\
5 & Others & 3 & 1,26 \\
\hline
\end{tabular}

This dosage form is directly proportional to the indication of the medicine most kept by household, are cough and flu (28.81\%). Research conducted in Bantul stated that flu and cough are among the top three diseases that people do themselves without a doctor's prescription [10]. This could be due to previous experience taking medication, or getting recommendations from pharmacists and commercials on television. Other indications for drugs that people keep at home are analgesics and antipyretics. This class of drugs ranks first for non-prescription drugs purchased by people in Bantul, Yogyakarta [10]. In contrast to the results of this study, in Magelang, this group ranks second after flu and cough. Different climatic and environmental conditions, disease trends and treatment among individuals also vary. The Table 3 presents data on drug storage based on the indication.

Table 3. Indication for Medicines Stored at home

\begin{tabular}{llll}
\hline No & Indication & Total & $\%$ \\
\hline 1 & Flu and Cough & 104 & 28,81 \\
2 & Headache & 85 & 23,55 \\
3 & Fever & 60 & 16,62 \\
4 & others & 29 & 8,03 \\
5 & Pain & 26 & 7,20 \\
6 & Eye/nose/ear pain & 14 & 3,88 \\
7 & Hypertension & 7 & 1,94 \\
8 & Diabetes & 2 & 0,55 \\
\hline
\end{tabular}

Most of the people keep their medicines so that they can using again on another day $(61 \%)$ and as supplies $(66.80 \%)$. Drug storage requires special attention. Because if not true it can damage and decrease its effectiveness so that the expected effect is not achieved. Other than that, it can cause poisoning when consumed, so drug storage needs to pay attention to the instructions listed on the packaging [11]. Most of the reasons for storing medicines at home can be due to changes in the diagnosis of the disease so that the medicine has also changed, and then there are side effects of the drug, changes in dosage, expired drugs, and patient non-compliance in taking them. Medicine [12]. Storage must adjust to the characteristics of each drug so that the quality remains good at the time of consumption. Improper drug storage can decrease the stability of the drug which has an impact on the effectiveness of the drug in providing a therapeutic effect in each person [13]. Research conducted in China states that when people store medicine only pay attention to the expiration date, they do not pay attention to other things, for example about the stability and temperature-humidity of the drug [14]. This is also, in line with what is happening in our immediate community. When buying medicine, they look at the 
name of the medicine, and then ask for the price and the expiration date. When the expiration date still long, they can store the drug freely, without considering other factors. The negligible length of time and storage temperature may lead to different estimates of the toxicity impact of the drug [15]. The location for storing medicines at home is also important to note. As many as $55.27 \%$ of people in Magelang store their medicines on the dining table. This can occur because of the ease in reaching the drug at the time of consumption it was easier for them to remember when they took the medicine before or after eating, or at the same time as eating, so they put the medicine on the table.

Ease of access to drugs is in accordance with the basic guidelines for drug storage; however, the negative impact if the medicine is on the dining table is easy for children to reach. It will be fatal if the placed drug has a narrow therapeutic index so that it can cause a sentinel event otherwise consume accordingly to the purpose and dose. Medicines to have at home be stored in one container, for example, a medicine box (P3K Box) so that it is easy to find when needed. Medicine city should be stored in a dry place away from light, heat and humidity. The kitchen or bathroom room is not suitable for storing medicine because the room conditions are usually hot and humid so that it quickly destroys the drug [16]. In the community service activities carried out in Cilacap, there was an increase in people's attitudes and knowledge of about $10 \%$ in terms of drug management, one of which is the proper and correct storage of medicines in the household. This situation occurs after training and mentoring by pharmacists [17]. Table 4 below shows the location for storing medicines at home.

Table 4. Location of Storing Medicine At home

\begin{tabular}{llcc}
\hline No & Location & Total & $\%$ \\
\hline 1 & in the closet & 113 & 36.10 \\
2 & in the refigerator & 19 & 6.07 \\
3 & on the dining table & 173 & 55.27 \\
4 & in the drawer & 3 & 0.96 \\
5 & in the bedroom & 1 & 0.32 \\
6 & in the medicine box & 1 & 0.32 \\
7 & hung on the wall & 3 & 0.96 \\
\hline
\end{tabular}

Most of the respondents disposed of the medicine in the form of tablets $(61.80 \%)$, then ointment/cream (60.96\%), powder (57.62\%) and suppositories (52.40) by throwing them directly into the trash. without giving treatment first. This is because replacing damaged or expired drugs from their original form can reduce the quality, safety and efficacy of the drug. In addition, because pharmaceutical preparations or drugs are included in as hazardous and toxic waste, they are dangerous if disposed of carelessly. The long-term effects of this can be devastating the environment, which affects humans, plants and animals, as well as open opportunities individuals to abuse medicinal waste. For syrup processing, people destroy it by first throwing the contents into the sink (33.84\%). It is also inappropriate to do this because drugs are chemicals that can harm living things.

According to the FDA, it is not permissible to flush medication down the toilet or sink unless specifically instructed [18]. A study conducted in China stated that only about $12.3 \%$ of people thought that eradication of drugs in the country required the most attention and $14.7 \%$ of the special culling process did not attract the attention of the local population [14]. Since 2010, the United States has implemented dropboxes as an official collection point for medicines that are not used in health facilities such as hospitals, pharmacies and clinics, thereby ensuring the safety of medicines that are no longer used in the community [19]. Dispose of the medicine 
and its packaging in the trash as long as they are not disposed of in their original form, so mixing the drug with soil is one way to do it before throwing it away. This prevents drug abuse or drug repackaging and minimizes environmental damage. This is also in line with the program that has been implemented by the National Food and Drug Agency (BPOM) since 2019, namely the Eradication of Drugs and Drug Abuse (POIPO) in order to create Superior HR for Advanced Indonesia [20].

The data on how to destroy drugs is directly proportional to the public belief that throwing unused or expired drugs into the trash (54\%) and burning it with other waste $(43.1 \%)$ is the right thing. Therefore, there is a need for intensive information and the Government through the Health Office and from related associations (Indonesian Pharmacist Association) can provide training that. Research that has been conducted on pharmacy students and nurses in Saudi Arabia show that $91.9 \%$ and $81.8 \%$ accept that the improper disposal of unused and expired drugs can affect the environment and health [21]. Figure 1 shows how to dispose of medicinal waste in households.

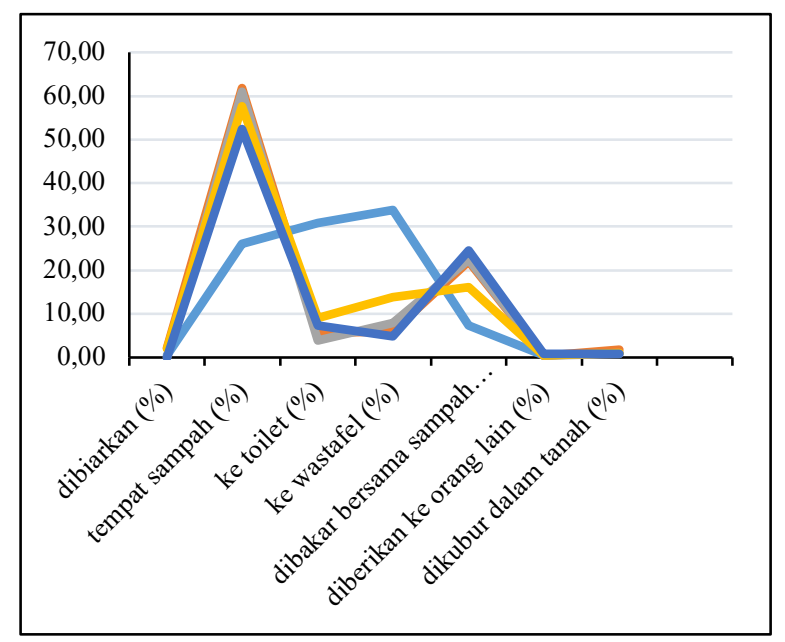

Fig.1. How to dispose of drug waste in the household.

The results of this study, the community stated that they had never $(65 \%)$ received any training or information regarding the storage and disposal of drugs from anyone. They should be able to get information and training from the relevant government because $38.1 \%$ of respondents agree that the government is responsible. As much as $21.3 \%$ said that important events like this are the responsibility of all parties because if it were only the responsibility of the government, the scope would not be broad due to limited human resources in the government. The community agreed (43.1) and strongly agreed (24.3\%) if packages or medicines that were not used/damaged/expired at home could be thrown away or returned to the nearest health facility. If drug waste management runs in an organized manner at the nearest health facility, then it can maintain the safety of the environment and living things around it and minimizes the reprocessing of drugs or fake or illegal drugs. Figure 2 shows about belief in taking out the unused medicine in household. 


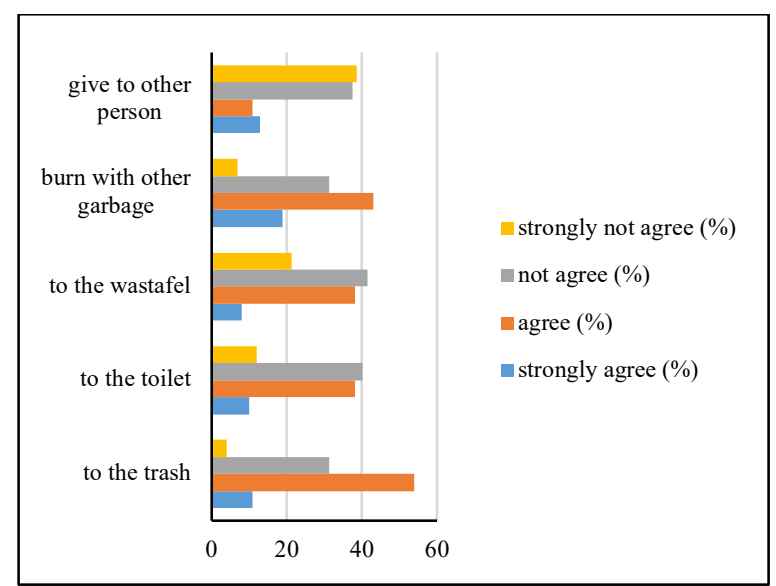

Fig.2. Belief in taking out the unused medicine in household.

The government, through the National Food and Drug Supervisory Agency (BPOM), has announced the proper disposal of drug waste. Starting October 11, 2019, people can destroy or dispose of unused/expired/damaged drugs at the nearest pharmacy, because BPOM has distributed 1000 boxes of drug waste in 15 cities in Indonesia with the aim of minimizing the occurrence of drug and illegal drug abuse. In Indonesia. However, not all cities have received this program, for example in Magelang, so the health office as an extension of the government can provide socialization and training in advance in the regions.

\section{Conclusion}

The conclusion of this study is that as many as $54 \%$ of people in Magelang believe that it is the right thing to throw unused or expired drugs in the trash $(65 \%)$ like other household waste. This can happen because many people $(65 \%)$ have never been able to socialize about the correct way to dispose of drugs. this can result in the community not knowing the risks or impacts that will occur in the future. The community hopes that the government or its representatives (BPOM) can reach small areas so that they can participate in the "how to properly dispose of drug waste" program. Besides that, cooperation between the Government and related professional associations is very necessary. For example, to provide training and outreach on how to manage medicines at home, especially in the proper storage and disposal of medicines to the community.

\section{References}

[1] Databoks, "Jumlah Penduduk Indonesia Tahun 2019," Databoks.Katadata.co.id, 2020. [Online]. Available: https://databoks.katadata.co.id/datapublish/2019/01/04/jumlah-penduduk-indonesia2019-mencapai-267-juta-jiwa. [Accessed: 21-Feb-2020].Charities Aid Foundation (CAF). 2018. World Giving Index 2018 A Global View of Giving Trend 
[2] Databoks, "Jumlah Penduduk Indonesia Tahun 2019," Databoks.Katadata.co.id, 2020. [Online]. Available: https://databoks.katadata.co.id/datapublish/2019/01/04/jumlah-penduduk-indonesia2019-mencapai-267-juta-jiwa. [Accessed: 21-Feb-2020].

[3] N. A. Harahap, Khairunissa, and J. Tanuwijaya, "Tingkat Pengetahuan Pasien dan Rasionalitas Swamedikasi di Tiga Apotek Kota Penyabungan,” J. Sains Farm. dan Klin., vol. 3, 2017.

[4] Y. Liana, "Analisis faktor-faktor yang mempengaruhi keluarga dalam penggunaan obat tradisional sebagai swamedikasi di Desa Tuguharum Kecamatan Madang Raya," Jkk, vol. 4, no. 1, pp. 121-128, 2017.

[5] A. M. Asrun, L. A. Sihombing, and Y. Nuraeni, "Dampak Pengelolaan Sampah Medis Dihubungkan dengan Undang- Undang No 36 Tahun 2009 tentang Kesehatan dan Undang-Undang No. 32 Tahun 2009 Tentang Perlindungan Dan Pengelolaan Lingkungan Hidup,” PAJOUL (Pakuan Justice J. Law), vol. Volume 01, no. 1, pp. 33-46, 2020.

[6] Iswanto, Sudarmadji, E. T. Wahyuni, and A. H. Sutomo, "Timbulan Sampah B3 Rumah Tangga dan Potensi Dampak Kesehatan Lingkungan Di Kabupaten Sleman, Yogyakarta,” Mns. dan Lingkung., vol. 23, no. 2, pp. 179-188, 2016.

[7] Y. Nuryeti and Y. Ilyas, "Pengelolaan Obat Kedaluwarsa dalam Upaya Pengendalian Pencemaran Lingkungan di Puskesmas Wilayah Kerja Kota Serang,” Hig. J. Kesehat. Lingkung., vol. 4, no. 3, pp. 138-142, 2018.

[8] C. AZAN, S. A. Kristina, and C. Wiedyaningsih, "Praktik Dan Keyakinan Tentang Pembuangan Obat Obatan Yang Tidak Digunakan Oleh Masyarakat Di Provinsi Daerah Istimewa Yogyakarta (DIY) Menggunakan Kuesioner Online," Gadjah Mada, 2019.

[9] BPS, "Jumlah Penduduk 15 tahun keatas menurut jenis kegiatan selama seminggu yang lalu," $\begin{array}{lll}\text { magelangkab.bps.go.id, } 2019 . & \text { [Online]. }\end{array}$ https://magelangkab.bps.go.id/statictable/2019/11/15/786/jumlah-penduduk-berumur-15-tahunkeatas-menurut-jenis-kegiatan-selama-seminggu-yang-lalu-dan-jenis-kelamin-di-kabupatenmagelang-2018.html.

[10] G. Murtini, "Farmestika Dasar," Kemenkes RI, no. Bahan Ajar Cetak Kebidanan. Kementerian Kesehatan Republik Indonesia, p. 168, 2016.

[11] S. F. Candradewi, S. A. Kristina, F. Farmasi, U. A. Dahlan, and J. P. Soepomo, "Gambaran pelaksanaan swamedikasi dan pendapat konsumen apotek mengenai konseling obat tanpa resep di wilayah Bantul," vol. 7, no. 1, pp. 41-52, 2017.

[12] AKFAR PIM, "Penyimpanan Obat Yang Baik di Rumah," akademipim.ac.id, Malang, 2020.

[13] M. T. Gidey, A. H. Birhanu, A. G. Tsadik, A. G. Welie, and B. T. Assefa, "Knowledge, Attitude, and Practice of Unused and Expired Medication Disposal among Patients Visiting Ayder Comprehensive Specialized Hospital," Biomed Research International, 2020. [Online]. Available: https://www.ncbi.nlm.nih.gov/pmc/articles/PMC7463377/. [Accessed: 06-Feb-2020].

[14] Ervianingsih, C. Astari, I. Zahran, M. Mursyid, and A. S. Samsi, "Pengabdian Kefarmasian ' Ayo Buang Sampah Obat' di Kelurahan Latuppa Kecamatan Mungkajang Kota Palopo Provinsi Sulawesi Selatan," Reson. J. Pengabdi. Masy., vol. 3, no. 2, pp. 27-38, 2019.

[15] Y. Huang, L. Wang, C. Zhong, and S. Huang, "Factors influencing the attention to home storage of medicines in China," BMC Public Health, vol. 19, no. 1, pp. 1-10, 2019.

[16] M. Savira et al., "Praktik Penyimpanan Dan Pembuangan Obat Dalam Keluarga," J. Farm. Komunitas, vol. 7, no. 2, p. 38, 2020.

[17] F. Rahmawati, “Tips Menyimpan Obat Dirumah,” Tribun Jogja, Jogjakarta, p. 14, 2014.

[18] H. Wasito, H. Pratiwi, A. Wibowo, and N. K. Solihat, "Edukasi dan Peningkatan Kualitas Pengelolaan Obat di Rumah Tangga: Studi Kasus di Dusun Sidasari Wetan Desa Kubangkangkung Kawunganten Cilacap,” JATI EMAS (Jurnal Apl. Tek. dan Pengabdi. Masyarakat), vol. 2, no. 2, p. 93, 2018.

[19] FDA, "How to Dispose of Unused Medicines," FDA Consumer Health Information, no. June, US, pp. 1-2, Dec-2013.

[20] K. L. Egan, M. Wolfson, K. M. Lukacena, C. M. Z. Zelaya, M. S. McLeary, and D. W. Helmec, "Developing a health communication campaign for disposal of unused opioid medications," Addictive Behaviors $\quad$ Report, $2020 . \quad$ [Online]. Available: https://www.ncbi.nlm.nih.gov/pmc/articles/PMC7752658/. [Accessed: 10-Feb-2021]. 
[21] Biro Hubungan Masyarakat dan Dukungan Strategis Pimpinan, "Persempit Peredaran Obat Ilegal, Badan POM Luncurkan Gerakan "Ayo Buang Sampah Obat - Gerakan Waspada Obat Ilegal," pom.go.id, 2019. [Online].

Available: https://www.pom.go.id/new/view/more/berita/16783/Persempit-Peredaran-Obat-Ilegal--BadanPOM-Luncurkan-Gerakan----Ayo-Buang-Sampah-Obat-----Gerakan-Waspada-Obat-Ilegal.html. [Accessed: 12-Feb-2021].

[22] A. Bashatah and S. Wajid, "Knowledge and Disposal Practice of Leftover and Expired Medicine: A Cross-Sectional Study from Nursing and Pharmacy Students' Perspectives," International Journal of Environmental Research and Public Health, 2020. [Online]. Available: https:/www.ncbi.nlm.nih.gov/pmc/articles/PMC7142560/. [Accessed: 10-Feb-2021]. 